\title{
Usefulness for surveillance of hypertension prevalence studies in Latin America and the Caribbean: the past 10 years
}

\author{
Melissa S. Burroughs Peña, ${ }^{1}$ Carmen Verônica Mendes Abdala, ${ }^{2}$ \\ Luis Carlos Silva, ${ }^{3}$ and Pedro Ordúñez 4
}

Suggested citation Burroughs Peña MS, Abdala CVM, Silva LC, Ordúñez P. Usefulness for surveillance of hypertension prevalence studies in Latin America and the Caribbean: the past 10 years. Rev Panam Salud Publica. 2012;32(1):15-21.

ABSTRACT Objective. To compare the usefulness for surveillance of the peer-reviewed literature on the prevalence of hypertension in Latin America and the Caribbean published from 2001 to 2010 with a previous study of the published literature from 1962 to 2000.

Methods. A bibliographic search was conducted of publications from 2001 to 2010 that examined the prevalence of hypertension using MEDLINE and LILACS databases. The methodology of each paper was evaluated with the same critical appraisal tool used in the previous study. Results. A total of 81 papers were published from 2001 to 2010 on the prevalence of hypertension in Latin America and the Caribbean. Only 24 of these studies met the minimum methodologic criteria for evaluation. While the total number of studies published in the past 10 years exceeds the number published from 1962 to 2000, the percentage of studies that met the minimum methodologic criteria has not substantially increased. In addition to major methodologic shortcomings, less than $46 \%$ of the published studies reported rates of awareness, treatment, and control of hypertension. The hypertension prevalence estimates from the peer-reviewed literature range from $7 \%$ to $49 \%$. These studies were primarily done in urban centers and are not evenly distributed throughout the region.

Conclusions. The quality and geographic distribution of the published literature on the prevalence of hypertension in Latin America and the Caribbean are inadequate. Research resources and efforts should be directed in the future toward closing this gap.

Key words Hypertension; risk factors; epidemiological surveillance; cross-sectional studies; Latin America; Caribbean region.

Division of Cardiology, Duke University, Durham, North Carolina, United States of America.

2 Latin American and Caribbean Center on Health Science Information (BIREME/PAHO/WHO), São Paulo, Brazil

3 Instituto Superior de Ciencias Médicas de La Habana, Habana, Cuba.

4 Chronic Disease Prevention and Control, Pan American Health Organization, Washington, D.C., United States of America. Send correspondence to: Pedro Orduñez, ordunezp@paho.org
The United Nations High-Level Meeting on Non-Communicable Diseases in September 2011 brought to the forefront the significance of noncommunicable diseases (NCDs) for global health and for development. This meeting highlighted the threat of NCDs to the economies of developing countries and called for a commitment from governments, the private sector, and nongovernmental organizations to establish programs and policies to address the rising epidemic (1). NCDs are the number one cause of death worldwide, accounting for $63 \%$ of deaths in 2008 with projections to increase by 15\% between 2010 and 2020 (2). In Latin 
America and the Caribbean, NCDs have an even greater impact on mortality and accounted for $73 \%$ of deaths and $76 \%$ of disability-adjusted life years in 2000 (3). In addition to causing mortality, NCDs often require costly treatments over a considerable amount of time, which can have a catastrophic financial impact on individuals and families, thus worsening poverty. The economic strain on families and health systems combined with lost economic productivity significantly affects national economies with the greatest impact on low- and middle-income countries $(2,4-7)$.

Cardiovascular disease, such as ischemic heart disease and cerebrovascular disease, is the most common NCD worldwide, accounting for $48 \%$ of all NCD deaths and killing 17 million people every year (2). Among the risk factors for cardiovascular disease, hypertension is one of the most important. It affects nearly 1 billion people and causes $8 \%$ of deaths worldwide (2). Moreover, while the prevalence of hypertension is decreasing in high-income countries, it seems to be rising at alarming rates in low- and middleincome countries (8). The surveillance of cardiovascular disease risk factors, such as hypertension, has been identified as a global health priority in order to estimate the burden and trends and appropriately direct resources and measure the effect of interventions $(2,5,6,9)$. Yet, despite the heavy burden of hypertension faced by low- and middle-income countries, many countries lack quality data or representative national studies, which may include data from surveys, registries, and administrative sources, all of which are necessary in order to quantify the magnitude of that burden and guide policies and interventions $(2,5,6,9,10)$.

Of the 35 countries in Latin America and the Caribbean, only 9 countries have recent data on hypertension from national studies (11). In the absence of representative national studies, it has been difficult to estimate the prevalence and trend of hypertension in Latin America and the Caribbean with any accuracy. In 2001, the available literature on the prevalence of hypertension in Latin America and the Caribbean from 1962 to 2000 was evaluated to determine its usefulness for population surveillance (12). At that time, only 28 studies from 1962 to 2000 met the minimum threshold for usefulness, with the following distribution upon further analysis: minimally useful, 16 studies; useful, 8 studies; very useful, 4 studies. While many of the studies reviewed may have been useful for other public health purposes such as evaluation of local and regional health care systems, most of the studies were not useful for epidemiologic surveillance. Although there have been advances in the surveillance of hypertension in Latin America and the Caribbean in the past 10 years, it is unclear if the current data are sufficient to be useful for surveillance purposes.

The main objective of this paper is to compare the usefulness for surveillance of the peer-reviewed literature on the prevalence of hypertension in Latin America and the Caribbean published from 2001 to 2010 with a previous study of the published literature from 1962 to 2000.

\section{METHODS}

A bibliographic search (available at http: / / search.bvsalud.org/hiperten sion/) was conducted in MEDLINE (for international literature in the medical and biomedical areas) and LILACS (for Latin American and Caribbean health sciences literature) from 2001 to 2010 using the following search terms in English, Spanish, and Portuguese: hypertension, high blood pressure, prevalence, population, community, epidemiology, Latin America, South America, Central America, Caribbean, and the names of all the countries in Latin America and the Caribbean. The bibliographic search results were then reviewed. In order to compare similar studies, those that did not measure the prevalence of hypertension, on white coat hypertension and prehypertension, or on pediatric populations were excluded. Studies of elderly populations, telephone surveys, studies that did not report an overall prevalence of hypertension for the study population, and studies that did not define hypertension as blood pressure greater than $140 / 90 \mathrm{mmHg}$ were included in the initial assessment but were considered not useful for epidemiologic surveillance.

The remaining studies were evaluated with an established tool described in a previous analysis on prevalence studies of hypertension (13). The first four questions of the tool establish the minimum criteria for usefulness for surveillance purposes: the study must be population based, the sampling design must be described, the sampling design must be probabilistic, and estimates must be given by sex and age groups. Those studies that met the minimum criteria for evaluation underwent full evaluation and were given a score. Based on the score, the studies were classified as minimally useful (score < 35), useful (score 35-69), and very useful (score $\geq 70$ ). These evaluations were then compared with the results of the prior study of hypertension prevalence studies published from 1962 to 2000 (12).

\section{RESULTS}

The initial bibliographic search on hypertension in Latin America and the Caribbean resulted in 487 citations. When the search was narrowed to include only population studies on the prevalence of hypertension, 146 citations remained. Finally, 81 of 146 papers were included in the analysis, after the papers were reviewed more closely and duplicate citations; publications that did not report the prevalence of hypertension; and publications on prehypertension, white coat hypertension, and pediatric hypertension were excluded. Table 1 presents the percentage of the 81 papers on hypertension in Latin America and the Caribbean from 2001 to 2011 that met specific methodologic criteria and compares this data with that for the articles from 1962 to 2000. The percentage of papers that met the four basic methodologic criteria for the earlier period is similar to the percentage for the 2001-2010 period. For example, only about $70 \%$ of the papers on the prevalence of hypertension used a probabilistic sample, which is very similar to the percentage of papers written before 2001.

Of the 81 papers that were considered in this study, 24 papers met the minimum methodologic criteria to be considered useful for purposes of epidemiologic surveillance. One study, which included data from seven countries is of particular note. In evaluating these 24 papers, the distribution was the following: minimally useful (score < 35), 1 study; useful (score 35-69), 17 studies; very useful (score $\geq 70$ ), 6 studies. In further evaluating the 24 papers that met all four minimum methodologic 
TABLE 1. Reviewed studies that met specific methodologic requirements for hypertension prevalence studies in Latin America and the Caribbean: comparison of 1962-2000 and 2001-2010

\begin{tabular}{|c|c|c|c|c|c|}
\hline \multirow[b]{2}{*}{ Question number } & \multirow[b]{2}{*}{ Question } & \multicolumn{2}{|c|}{ 1962-2000 } & \multicolumn{2}{|c|}{ 2001-2010 } \\
\hline & & $\%$ & No. & $\%$ & No. \\
\hline \multicolumn{2}{|l|}{ Basic aspects } & & $n=58$ & & $n=81$ \\
\hline A & Is the problem being studied on a general population? & 75.9 & 44 & 80.2 & 65 \\
\hline $\mathrm{B}$ & Is the study's sampling design fully described? & 74.1 & 43 & 77.8 & 63 \\
\hline C & Was a probabilistic sample used? & 69.0 & 40 & 70.4 & 57 \\
\hline D & Are prevalences given by age groups and sex? & 67.2 & 39 & 67.9 & 55 \\
\hline \multicolumn{2}{|c|}{ Complementary aspects } & & $n=28$ & & $n=24$ \\
\hline 1 & Is the problem under study described in both qualitative and quantitative terms? & 63.8 & 18 & 100.0 & 24 \\
\hline 2 & Were standardized techniques used to measure arterial blood pressure? & 79.3 & 22 & 100.0 & 24 \\
\hline 3 & Were universally accepted cut-offs used in diagnosing the ailment? & 84.5 & 24 & 100.0 & 24 \\
\hline 4 & Did the data collectors receive training? & 58.6 & 16 & 83.3 & 20 \\
\hline 5 & Were certified instruments and observers used? & 46.6 & 13 & 25.0 & 6 \\
\hline 6 & Was there quality control of the data? & 41.4 & 12 & 29.2 & 7 \\
\hline 7 & Were estimates calculated according to the sampling design? & 25.9 & 7 & 41.7 & 10 \\
\hline 8 & Were estimates made by place of residence, occupation, or education level? & 50.0 & 14 & 66.7 & 16 \\
\hline 9 & Are the errors of the estimates reported according to the sampling design? & 10.3 & 3 & 62.5 & 15 \\
\hline 10 & Are extrapolations explained or discussed? & 53.4 & 15 & 75.0 & 18 \\
\hline 11 & Are any qualitative judgments made that can serve as the basis for action? & 72.4 & 20 & 95.8 & 23 \\
\hline \multicolumn{2}{|c|}{ Hypertension-specific questions } & & $n=28$ & & $n=24$ \\
\hline 12 & In addition to prevalence, was mean blood pressure estimated? & 55.2 & 15 & 25.0 & 6 \\
\hline 13 & Is the percentage of hypertensive individuals who know their condition indicated? & 24.1 & 7 & 45.8 & 14 \\
\hline 14 & Is the percentage of hypertensive individuals under treatment indicated? & 31.0 & 9 & 41.7 & 10 \\
\hline 15 & Is the percentage of hypertensive individuals whose disease is under control indicated? & 19.0 & 5 & 45.8 & 14 \\
\hline
\end{tabular}

criteria, there is discrete improvement in quality compared with the published literature from 1962 to 2000. The largest improvement is in the percentage of papers that report errors in the prevalence estimates, which has increased from $10.3 \%$ to $62.5 \%$ (Table 1 ). Other substantial improvements occurred in the percentage of studies with trained data collectors and estimates calculated according to sampling method. However, there were fewer studies that reported the use of quality control of the data in 2001-2010 than in 1962-2000 period. Moreover, despite modest improvement compared with 1962-2000, less than 46\% of the literature published from 2001 to 2010 reported awareness, treatment, and control of hypertension in the population studied.

The 24 studies that met the minimum methodologic criteria do not represent all Latin America and Caribbean countries equally (Table 2) (14-37). One study reported data on hypertension in seven countries in South America. However, none of the Central American countries had data that could be considered useful for surveillance. Fifteen of the 24 studies that were considered useful for surveillance were done in Brazil. Of those, 13 were done in the southeastern region of the country. Within the Caribbean, four articles were based on studies conducted in Cuba, Guadeloupe, Haiti, and Martinique. None of the Englishspeaking Caribbean countries had any published literature that met the minimum criteria.

The hypertension prevalence estimates from Latin America and the Caribbean range from $7 \%$ to $49 \%$ (Table 2 ). Among the peer-reviewed literature in the past 10 years, Haitian men have the highest prevalence of hypertension at $49 \%$, as estimated in one study in urban Haiti (score = 35). While Brazil is the only other country to report a prevalence of hypertension $\geq 40 \%$, Argentina and Guadeloupe had studies that estimated the prevalence of hypertension to be $>30 \%(14,22,34)$. The lowest reported hypertension prevalence $(<20 \%)$ occurred in Mexico and South America-specifically, Colombia, Ecuador, and Peru (15). There were significant differences in hypertension prevalence estimates even within countries. For example, depending on the location in Brazil where the hypertension studies were done, the estimated prevalence ranged from as low as $22 \%$ to as high as $41 \%(18,25)$.

\section{DISCUSSION}

Although 487 studies have been published in the past 10 years on hyperten- sion in Latin America and the Caribbean, which is considerably more than the 69 papers published from 1962 to 2000, most of these studies did not meet the basic methodologic criteria to be considered useful for surveillance purposes. Eighty-four percent of the studies of the prevalence of hypertension in Latin America and the Caribbean in the past 10 years cannot be used for surveillance. In addition, a considerable amount of studies did not describe the sampling design. Without explaining the method by which the sample was designed, it is impossible to understand whether the results can be extrapolated to a greater population. The percentage of studies that use a probabilistic sample and report prevalence estimates by age and sex has not increased in the past 10 years. This finding illustrates the fact that while there has been some improvement in the quantity of published literature on the prevalence of hypertension, what has been published is not sufficient for the surveillance of hypertension in Latin America and the Caribbean.

Of the 24 research studies that met the basic methodologic requirements, many key elements were missing. The prevalence of hypertension by age and sex was not reported in many of the studies. Hypertension is associated with increased age and can affect men and 
TABLE 2. Reported prevalence of hypertension in Latin America and Caribbean countries from peer-reviewed literature, 2001-2010

\begin{tabular}{|c|c|c|c|c|c|c|c|c|c|c|c|c|}
\hline \multirow[b]{2}{*}{ Country } & \multirow{2}{*}{$\begin{array}{c}\text { Ref. } \\
\text { no. }\end{array}$} & \multirow[b]{2}{*}{ Year } & \multirow[b]{2}{*}{ Setting } & \multirow{2}{*}{$\begin{array}{c}\text { Age } \\
\text { (years) }\end{array}$} & \multirow[b]{2}{*}{ No. } & \multirow[b]{2}{*}{$\%$} & \multirow[b]{2}{*}{$95 \% \mathrm{Cl}$} & \multicolumn{5}{|c|}{ Prevalence (\%) } \\
\hline & & & & & & & & Men & Women & Awareness & Treatment & Control \\
\hline Argentina & 14 & 2001 & Rural/town & $15-75$ & 1523 & 35.8 & NA & 43.2 & 28.5 & 32.0 & 28.0 & 4.0 \\
\hline Argentina & 15 & 2010 & Urban & $25-64$ & 1482 & 29.0 & 26.9-31.1 & 37.7 & 21.7 & 64.1 & NA & 18.0 \\
\hline Brazil & 16 & 2001 & Urban & $\geq 20$ & NA & NA & NA & NA & NA & NA & NA & NA \\
\hline Brazil & 17 & 2001 & Rural & $\geq 18$ & 2314 & 24.8 & NA & 22.0 & 26.9 & NA & NA & NA \\
\hline Brazil & 18 & 2001 & Urban & $\geq 18$ & 688 & 31.5 & NA & 33.9 & 29.9 & 77 & 61.8 & 17.1 \\
\hline Brazil & 19 & 2003 & Rural/urban & $20-69$ & 411 & 35.5 & $30.9-40.3$ & 40.1 & 32.2 & 46.6 & 29.5 & 9.7 \\
\hline Brazil & 20 & 2005 & Urban & $\geq 30$ & 1137 & 22.5 & NA & 24.6 & 20.6 & NA & NA & NA \\
\hline Brazil & 21 & 2006 & Urban & $18-80$ & 1174 & 34.7 & $32.2-37.4$ & 35.0 & 34.4 & NA & NA & NA \\
\hline Brazil & 22 & 2007 & Urban & $\geq 18$ & 707 & 40.5 & $36.8-44.2$ & 43.3 & 38.3 & 55.6 & 46.8 & 10.1 \\
\hline Brazil & 23 & 2007 & Urban & $20-60$ & 1020 & NA & NA & NA & $\begin{array}{c}26.2 \\
(23.5-28.9)\end{array}$ & NA & NA & NA \\
\hline Brazil & 24 & 2008 & Urban & $\geq 18$ & 835 & 27.4 & $24.4-30.6$ & 32.1 & 24.2 & NA & NA & NA \\
\hline Brazil & 25 & 2008 & Urban & $\geq 18$ & 1717 & 25.2 & 22.7-27.7 & NA & NA & NA & NA & NA \\
\hline Brazil & 26 & 2009 & Urban & $\geq 20$ & 3180 & 29.5 & NA & 27.7 & 30.9 & NA & NA & NA \\
\hline Brazil & 27 & 2009 & Urban & $20-59$ & 2022 & 33.7 & $31.7-36.1$ & 31.1 & 38.1 & NA & NA & NA \\
\hline Brazil & 28 & 2009 & Urban & $\geq 18$ & 1168 & 32.7 & NA & 35.8 & 30.9 & NA & NA & NA \\
\hline Brazil & 29 & 2009 & Rural & $18-90$ & 1003 & 30.1 & NA & NA & NA & 73.5 & 61.9 & 24.2 \\
\hline Brazil & 30 & 2010 & Urban & $\geq 18$ & 1717 & 25.2 & $21.4-30.0$ & 23.8 & 26.8 & 74.4 & NA & 34.3 \\
\hline Chile & 31 & 2007 & Urban & $\geq 15$ & 8472 & 21.7 & NA & 20.0 & 23.0 & 66.6 & 59.9 & 30.7 \\
\hline Chile & 15 & 2010 & Urban & $25-64$ & 1655 & 23.8 & $21.6-26.1$ & 27.3 & 20.7 & 60.1 & NA & 20.3 \\
\hline Colombia & 32 & 2002 & Urban & $\geq 20$ & 356 & 22.9 & $18.6-27.3$ & 29.8 & 17.2 & NA & NA & NA \\
\hline Colombia & 15 & 2010 & Urban & $25-64$ & 1553 & 13.4 & $11.5-15.2$ & 14.6 & 12.4 & 68.8 & NA & 30.6 \\
\hline Cuba & 33 & 2008 & Urban & $25-74$ & 1475 & 21.4 & $17.5-25.3$ & 23.4 & 20.0 & 78.5 & 61.2 & 39.9 \\
\hline Ecuador & 15 & 2010 & Urban & $25-64$ & 1638 & 8.6 & $7.3-10.0$ & 7.2 & 10.1 & 67.6 & NA & 28.0 \\
\hline Guadeloupe & 34 & 2010 & Urban/rural & $25-74$ & 1005 & NA & NA & 33.1 & 37.3 & NA & NA & NA \\
\hline Haiti & 35 & 2006 & Urban & $\geq 20$ & 1620 & NA & NA & 48.7 & 46.5 & NA & NA & NA \\
\hline Martinique & 36 & 2009 & Rural/urban & $\geq 16$ & 1504 & 22.5 & $20.1-25.1$ & 20.0 & 25.0 & NA & 16.0 & NA \\
\hline Mexico & 15 & 2010 & Urban & $25-64$ & 1720 & 11.7 & $10.3-13.1$ & 11.2 & 12.1 & 75.7 & NA & 41.0 \\
\hline Peru & 37 & 2009 & Urban & $20-80$ & 1878 & 15.7 & $14.0-17.4$ & 16.0 & 15.4 & 47.9 & 39.5 & 14.0 \\
\hline Peru & 15 & 2010 & Urban & $25-64$ & 1652 & 12.6 & $11.1-14.0$ & 14.4 & 10.7 & 53.1 & NA & 12.0 \\
\hline Venezuela & 15 & 2010 & Urban & $25-64$ & 1848 & 24.7 & $22.7-26.8$ & 27.5 & 22.9 & 72.0 & NA & 20.7 \\
\hline
\end{tabular}

Note: $\mathrm{Cl}$ : confidence interval, NA: not available.

women differently, thus knowing the variance across age and sex is crucial for epidemiologic surveillance. Moreover, given that most studies did not recruit participants in proportion to the age and sex distribution of the studied population, it is necessary to weigh the prevalence of hypertension found for these groups in order to estimate the actual prevalence in the entire population. Sampling error is critical to understanding how well the actual prevalence of hypertension is estimated. Many of the studies considered have relatively small sample sizes, which increase the width of the $95 \%$ confidence interval of the hypertension prevalence estimates. The prevalence estimates from these smaller studies are therefore less precise and less useful in epidemiologic surveillance.

While there was considerable improvement in the percentage of studies that used trained data collectors to measure blood pressure, many studies did not use certified instruments or have quality control measures. Given the complexity and variability of blood pressure measure- ment, it is necessary to have standardized instruments and procedures and to have data collectors who are well trained in those procedures. Both user error and error related to faulty sphygmomanometers can greatly affect prevalence estimates of hypertension in a research study. In addition to methodologic concerns, many of the studies on hypertension did not report other aspects of hypertension care that are important for surveillance. Data on hypertension awareness, treatment, and control are critical to developing strategies for intervention and evaluating interventions. Without understanding these three elements of hypertension care, it will be difficult to know how to direct scarce public health resources most effectively in order to improve cardiovascular outcomes.

Many countries in Latin America and the Caribbean did not have published literature on hypertension in the past 10 years that could be used for surveillance. Similar to 1962-2000, there were no published studies in Central America that met the minimum methodologic criteria to be useful for surveillance from 2001 to 2010. The double burden of infectious disease and NCD may account for why hypertension and other cardiovascular disease risk factors have not been prioritized in health surveillance. Moreover, it is particularly concerning that only four studies from the Caribbean are useful for surveillance. The Caribbean is a region for which the prevalence of hypertension previously has been estimated to be very high and where stroke is the leading cause of death. The fact that Caribbean countries such as the Dominican Republic, Jamaica, and Trinidad and Tobago have not had any published studies in the past 10 years that are useful for hypertension surveillance underscores the fact that hypertension surveillance has not received the appropriate allocation of resources for research in proportion to the burden of disease in the region.

Most of the 24 studies that met the minimum methodologic criteria were published in South America. Fifteen of them were conducted in Brazil, which is a dramatic increase compared with 
the 1962-2000 period when no Brazilian studies met the minimum criteria. Despite this improvement, the 15 studies were not distributed evenly throughout Brazil; 13 were conducted in the southeastern region, which is the wealthiest area in the country. A few studies included communities of low socioeconomic status located in the southeastern region of Brazil, but other low-income regions of Brazil were neglected.

Although examining the distribution of hypertension studies within countries was not a primary objective of this paper, it was observed that most of the studies on the prevalence of hypertension in Latin America and the Caribbean were conducted in urban areas. Only 6 of the 24 studies were done in rural areas and small towns. While hypertension and other lifestyle-associated diseases tend to be more prevalent in urban areas, it is still necessary to study hypertension in rural areas and small towns in order to appropriately design and direct interventions. These marginalized areas may be particularly vulnerable as they may face an increased burden of infectious diseases in addition to a rising incidence of chronic disease. Ignoring chronic disease and the associated risk factors in rural areas may have detrimental consequences for public health.

There are several limitations to this review. Although the resources of The Latin American and Caribbean Center on Health Sciences Information (also known as BIREME) were used to conduct the literature search, it is possible that some of the published literature on hypertension in Latin America was not found. Moreover, the study included only literature published in peer-reviewed journals and excluded unpublished reports.
These unpublished reports include those from government and nongovernmental organizations. While the exclusion of gray literature may serve to add to the robustness of the literature reviewed by excluding papers that did not pass the peer-review process, the results are subject to publication bias. Another limitation of this paper is the exclusion of studies on prehypertension. These studies can be useful for surveillance and for development of interventions, but there were not enough studies on prehypertension to draw a meaningful comparison. Moreover, in comparing the literature on hypertension prevalence from before 2001 with literature from 2001 to 2010, the number of studies that met the minimum methodologic criteria was small. Thus, small changes in the number of studies that met certain methodologic criteria signify an improvement, even though the overall number of studies remains quite small.

The usefulness of the published literature for hypertension surveillance for Latin America and the Caribbean has not improved sufficiently in the past 10 years, with the exception of Brazil. In directing efforts to combat chronic disease-and, more specifically, cardiovascular disease-there should be a significant investment in epidemiologic research with the methodologic features to make such research useful to guide interventions. With the coordination of governments, universities, and research funding organizations, a more systematic manner of determining where hypertension studies are done and the methodology used in the studies should be established. A standardized methodology should be implemented with the coordination of national, bilateral, and international organizations. One example is the World Health Organization STEPS approach, which provides structure, tools, and priorities for public health entities to conduct NCD and NCD risk factor surveillance. In order to develop and implement effective interventions to address the rising burden of hypertension, an optimal research environment should be cultivated that includes a coordinated surveillance effort within countries and across the region (38). Not only should hypertension surveillance be a priority, but so should the surveillance of dietary habits, physical activity, and alcohol consumption, all of which are risk factors for hypertension and other NCDs. The burden of the hypertension epidemic is large and rising, as evidenced by the seven peer-reviewed publications in this study that reported hypertension prevalence estimates greater than or equal to that in the United States of America, which is currently estimated to be $30.9 \%$ (39). Given the potential costs of public health interventions and treatment for hypertension, it is imperative to appropriately direct these interventions and measure the outcomes $(38,40,41)$. Interventions directed at preventing and treating hypertension, including reducing salt intake, home health education, and medication, are cost-effective and often cost saving $(42,43)$. However, the opportunity for hypertension treatment and prevention is often overlooked in the face of the shrinking budgets of strained health systems. In the setting of the global economic crisis and the limited available resources for research, it is necessary that research studies meet the methodologic criteria to be useful for public health surveillance.

\section{REFERENCES}

1. United Nations General Assembly. SixtySixth Sessions. Political Declaration of the High-level Meeting of the General Assembly on the Prevention and Control on NoncommunicableDiseases. A/66/L.1.New York: United Nations; 2011. Available from: http:// daccess-dds-ny.un.org/doc/UNDOC/LTD/ N11 / 497/77/PDF/N1149777.pdf?Open Element Accessed 16 September 2011.

2. World Health Organization. Global status report on noncommunicable diseases 2010. Geneva: WHO; 2011.
3. Perel P, Casas JP, Ortiz Z, Miranda JJ. Noncommunicable disease and injuries in Latin America and the Caribbean: time for action. PLoS Med. 2006;3(9):1148-51.

4. Anderson GF, Chu E. Expanding priorities-confronting chronic disease in countries with low income. N Engl J Med. 2007;356(3): 209-11.

5. Beaglehole R, Bonita R, Horton R, Adams C, Alleyne G, Asaria P, et al. Priority actions for the non-communicable disease crisis. Lancet. 2011;377(9775):1438-47.
6. Miranda JJ, Kinra S, Casas JP, Davey Smith G, Ebrahim S. Non-communicable diseases in low- and middle-income countries: context, determinants and health policy. Trop Med Int Health. 2008;13(10):1225-34.

7. Abegunde DO, Mathers CD, Adam T, Ortegon $\mathrm{M}$, Strong K. The burden and costs of chronic diseases in low-income and middle-income countries. Lancet. 2007;370(9603):1929-38.

8. Anand SS, Yusuf S. Stemming the global tsunami of cardiovascular disease. Lancet. 2011;377(9765):529-32. 
9. Bonita R. Strengthening NCD prevention through risk factor surveillance. Glob Health Action. 2009;2(S1):4-6.

10. Castillo-Salgado C. Trends and directions of global public health surveillance. Epidemiol Rev. 2010;32(1):93-109.

11. Pan American Health Organization. Implementation of the regional strategy and plan of action for an integrated approach to the prevention and control of chronic diseases, including diet, physical activity and health. CD50/INF/6. Washington, D.C.: PAHO; 2010. Available from: http://new.paho.org/hq/ dmdocuments / 2010/CD50-INF-6-F-e.pdf Accessed 23 August 2011.

12. Ordúñez P, Silva LC, Rodríguez MP, Robles $\mathrm{S}$. Prevalence estimates for hypertension in Latin America and the Caribbean: are they useful for surveillance? Rev Panam Salud Publica. 2001;10(4):226-31.

13. Silva LC, Ordúñez P, Rodríguez MP, Robles $\mathrm{S}$. A tool for assessing the usefulness of prevalence studies done for surveillance purposes: the example of hypertension. Rev Panam Salud Publica. 2001;10(3):152-60.

14. Carbajal HA, Salazar MR, Riondet B, Rodrigo HF, Quaini SM, Rechifort V, et al. Variables asociadas a hipertensión arterial en una region de la Argentina. Medicina (Buenos Aires). 2001;61(6):801-9.

15. Hernández-Hernández R, Silva $H$, Velasco M, Pellegrini F, Macchia A, Escobedo J, et al. Hypertension in seven Latin American cities: the Cardiovascular Risk Factor Multiple Evaluation in Latin America (CARMELA) study. J Hypertens. 2010;28(1):24-34.

16. Sichieri R, Oliveira MC, Pereira RA. High prevalence of hypertension among black and mulatto women in a Brazilian survey. Ethn Dis. 2001;11(3):412-8.

17. Barreto SM, Passos VMA, Firmo JOA, Guerra HL, Vidigal PG, Lima-Costa MFF. Hypertension and clustering of cardiovascular risk factors in a community in southeast BrazilBambuí Health and Ageing Study. Arq Bras Cardiol. 2001;77(6):576-81.

18. Freitas OC, Carvalho FR, Neves JM, Veludo PK, Parreira RS, Goncalves RM, et al. Prevalence of hypertension in the urban population of Catanduva, in the state of Sao Paulo, Brazil. Arq Bras Cardiol. 2001;77(1):9-21.

19. Oliveira RZ, Nogueira JL. Hipertensão arterial no município de Cianorte, estado do Paraná, Brasil. Acta Sci Health Sci. 2003;25(1): 75-9.

20. Feijão AMM, Gadelha FV, Bezerra AA, Oliveira AM, Silva MSS, Lima JWO. Prevalência de excesso de peso e hipertensão arterial, em população urbana de baixa renda. Arq Bras Cardiol. 2005;84(1):29-33.

21. Wiehe M, Fuchs SC, Moreira LB, Moraes RS, Pereira GM, Gus M, et al. Absence of association between depression and hypertension: results of a prospectively designed population-based study. J Hum Hypertens. 2006;20(6):434-9.

22. Pereira MR, Coutinho MSSA, Freitas PF, D'Orsi E, Bernardi A, Hass R. Prevalência, conhecimento, tratamento e controle de hipertensão arterial sistêmica na população adulta urbana de Tubarão, Santa Catarina, Brasil, em 2003. Cad Saúde Pública. 2007;23(10):2363-74.

23. Hartmann M, Dias-da-Costa JS, Olinto MTA, Pattussi MP, Tramontini A. Prevalência de hipertensão arterial sistêmica e fatores associados: um estudo de base populacional em mulheres no Sul do Brasil. Cad Saúde Pública. 2007;23(8):1857-66.

24. Barbosa JB, Silva AA, Santos AM, Monteiro Junior FC, Barbosa MM, Barbosa MM, et al. Prevalence of arterial hypertension and associated factors in adults in São Luís, state of Maranhão. Arq Bras Cardiol. 2008;91(4): 236-42, 260-6.

25. Cesarino CB, Cipullo JP, Martin JF, Ciorlia LA, Godoy MR, Cordeiro JA, et al. Prevalence and sociodemographic factors in a hypertensive population in São José do Rio Preto, São Paulo, Brazil. Arq Bras Cardiol. 2008; 91(1):29-35.

26. Chrestani MAD, Santos IS, Matijasevich AM. Hipertensão arterial sistêmica auto-referida: validação diagnóstica em estudo de base populacional. Cad Saúde Pública. 2009;25(11): 2395-406.

27. Longo GZ, Neves J, Luciano VM, Peres MA. Prevalence of high blood pressure levels and associated factors among adults in southern Brazil. Arq Bras Cardiol. 2009;93(4):387-94, 380-6.

28. Nascente FMN, Jardim PCBV, Peixoto MRG, Monego ET, Barroso WKS, Moreira HG, et al. Hipertensão arterial e sua associação com índices antropométricos em adultos de uma cidade de pequeno porte do interior do Brasil. Rev Assoc Med Brás. 2009;55(6):716-22.

29. Rosário TM, Scala LCN, França GVA, Pereira MRG, Jardim PCBV. Prevalência, controle e tratamento da hipertensão arterial sistêmica em Nobres-MT. Arq Bras Cardiol. 2009;93(6):672-8.

30. Cipullo JP, Martin JF, Ciorlia LA, Godoy MR, Cacao JC, Loureiro AA, et al. Prevalência e fatores de risco para hipertensão em uma população urbana Brasileira. Arq Bras Cardiol. 2010;94(4):519-26.

31. Fasce E, Campos I, Ibáñez P, Flores M, Zárate $\mathrm{H}$, Román $\mathrm{O}$, et al. Trends in prevalence, awareness, treatment and control of hypertension in urban communities in Chile. J Hypertens. 2007;25(9):1807-11.

32. Bautista LE, Vera-Cala LM, Villamil L, Silva SM, Peña IM, Luna LV. Factores de riesgo asociados con la prevalencia de hipertensión arterial en adultos de Bucaramanga, Colombia. Salud Pública Méx. 2002;44(5):399-405.

33. Ordúñez P, Barceló A, Bernal JL, Espinosa A, Silva LC, Cooper RS. Risk factors associated with uncontrolled hypertension: findings from the baseline CARMEN survey in Cienfuegos, Cuba. J Hypertens. 2008;26(4):663-71.

34. Atallah A, Kelly-Irving M, Zouini N, Ruidavets JB, Inamo J, Lang T. Controlling arterial hypertension in the French West Indies: a separate strategy for women? Eur J Public Health. 2010;20(6):665-70.

35. Jean-Baptiste ED, Larco P, Charles-Larco N, Vilgrain C, Simon D, Charles R. Glucose intolerance and other cardiovascular risk factors in Haiti (PREDIAH). Diabetes Metab. 2006;32(5 Pt 1):443-51.

36. Merle S, Pierre-Louis K, Rosine J, Cardoso $\mathrm{T}$, Inamo J, Deloumeaux J. Prévalence de l'hypertension artérielle en population générale à la Martinique. Rev Epidemiol Sante Publique. 2009;57(1):17-23.

37. Medina Lezama J, Chirinos Medina J, Zea Díaz H, Morey Vargas O, Bolaños Salazar J, Cuba Bustinza C, et al. Aspectos epidemiológicos y hemodinámicos de la hipertensión y de la prehipertensión arterial en Arequipa. Resultados del estudio prevención. Rev Peru Cardiol (Lima). 2009;35(1):30-43.

38. Bakris G, Hill M, Mancia G, Steyn K, Black HR, Pickering T, et al. Achieving blood pressure goals globally: five core actions for health-care professionals. A worldwide call to action. J Hum Hypertension. 2008;22(1):63-70.

39. Centers for Disease Control and Prevention. Vital signs: prevalence, treatment and control of hypertension-United States, 1999-2002 and 2005-2008. MMWR Morb Mortal Wkly Rep. 2011;60(4);103-8.

40. Gaziano TA, Galea G, Reddy KS. Scaling up interventions for chronic disease prevention: the evidence. Lancet. 2007;370(9603):1939-46.

41. Bonita R. Guest editorial: strengthening NCD prevention through risk factor surveillance. Global Health Action. 2009;2(S1):4-6.

42. Bibbins-Domingo K, Chertow GM, Coxson PG, Moran A, Lightwood JM, Pletcher MJ, et al. Projected effect of dietary salt reductions on future cardiovascular disease. N Engl J Med. 2010;362(7):590-9.

43. Jafar TH, Islam M, Bux R, Poulter N, Hatcher $\mathrm{J}$, Chaturvedi $\mathrm{N}$, et al. Cost-effectiveness of community-based strategies for blood pressure control in a low-income developing country: findings from cluster-randomized, factorialcontrolled trial. Circulation. 2011;124:1615-25.

Manuscript received on 24 August 2011. Revised version accepted for publication on 13 February 2012. 
RESUMEN Objetivo. Comparar la utilidad para la vigilancia epidemiológica de los artículos sobre prevalencia de hipertensión en América Latina y el Caribe publicados en revistas con arbitraje científico del 2001 al 2010, con un estudio anterior de la

Utilidad de los estudios de prevalencia para la vigilancia de la hipertensión en América Latina y el Caribe: los 10 últimos años

Palabras clave bibliografía publicada en el período 1962-2000.

Métodos. En las bases de datos MEDLINE y LILACS se efectuó una búsqueda bibliográfica de los artículos que examinaron la prevalencia de hipertensión publicados del 2001 al 2010. La metodología empleada en cada artículo se valoró con la misma herramienta de evaluación usada en el estudio anterior.

Resultados. Del 2001 al 2010 se publicaron 81 artículos sobre la prevalencia de la hipertensión en América Latina y el Caribe. Solo 24 de estos estudios cumplieron los criterios metodológicos mínimos para la evaluación. Aunque en los 10 últimos años se publicaron más estudios que en el período 1962-2000, el porcentaje de estudios que cumplieron los criterios metodológicos mínimos no aumentó sustancialmente. Además de presentar deficiencias metodológicas importantes, menos de $46 \%$ de los estudios publicados incluyeron información sobre la concientización, el tratamiento y el control de la hipertensión. Las estimaciones sobre la prevalencia de hipertensión en los artículos estudiados varían entre 7\% y 49\%. Estos estudios se realizaron principalmente en centros urbanos y no se distribuyeron de manera uniforme en toda la región.

Conclusiones. La bibliografía publicada sobre la prevalencia de la hipertensión en América Latina y el Caribe es insuficiente para ser útil con fines de vigilancia, y su calidad y la distribución geográfica son inadecuadas. En el futuro, los recursos y los esfuerzos de investigación deben enfocarse en reducir esta diferencia.

Hipertensión; factores de riesgo; salud pública; vigilancia; América Latina; región del Caribe. 